associated with the invention that, perhaps more than any other, secured victory for the Allies in the Second World War.

Selman Waksman, by contrast, was a well respected researcher who forsook his principles for the irresistible prospect of lasting fame. The antibiotic streptomycin eventually saved the lives of innumerable consumptives, and earned Waksman a Nobel prize in 1952. His claim to have discovered the antibiotic essentially by himself was challenged by his student Albert Schatz, who went so far as to take his supervisor to court, an act that incurred the opprobrium of the scientific establishment for bringing their calling into disrepute. The affair put paid to Schatz's career, even though it was he who had on his own initiative isolated streptomycin and tested it against tubercle bacilli. As so often in such cases, the student was convinced that the credit was entirely his, while the professor believed that he had created the intellectual milieu which opened the way to the discovery. This does not exculpate Waksman, who had, as Waller shows, fallen into the grip of self-delusion. Friedrich Nietzsche explained this psychology most concisely: "'I have done this,' says my memory. 'I could not have done this,' says my pride, and remains adamant. At last memory yields."

Let me affirm finally that Leaps in the Dark is a good read, and ought to generate much healthy debate. Waller has opened what seems to be an inexhaustible vein one that will no doubt yield more highquality ore.

Walter Gratzer is at the Randall Division of Cell and Molecular Physics, King's College, New

Hunt's House, Guy's Campus, St Thomas' Street, London SE1 1UL, UK.

\section{Poison in the well}

\section{Venomous Earth: The World's}

Worst Mass Poisoning

by Andrew A. Meharg

Macmillan Science: 2005. 256 pp. 116.99 ,

$\$ 29.95$

\section{Roger P. Smith}

The dust-jacket shows cupped palms in a pose eerily reminiscent of that used by the US insurance company that bills itself: "The Good Hands People". The skin, however, is pigmented by the black raindrop pattern of melanosis characteristic of chronic arsenic poisoning. The victim is one of a predicted 350,000 people in Bangladesh and West Bengal, India, who will develop fatal cancers over the next ten years.

As one of the poorest nations in the world, Bangladesh has long lacked even necessities such as safe drinking water for its burgeoning population. Before the early

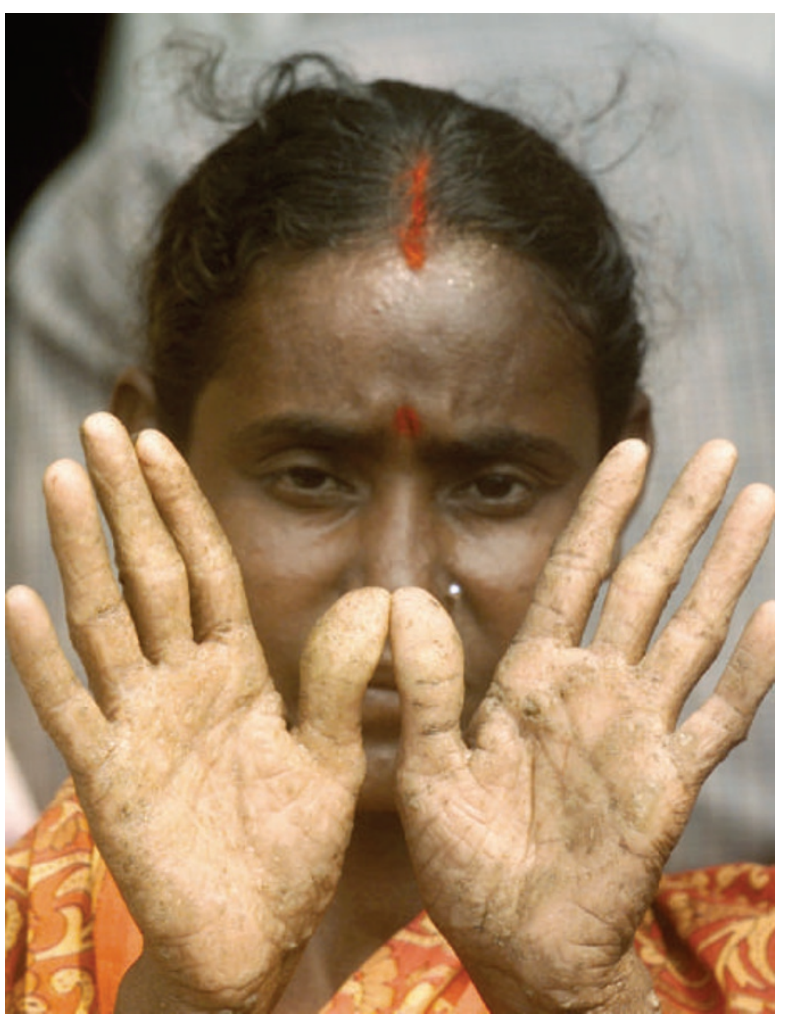

health benefits. The installation of the tubewells continued to accelerate. Cases of arsenic poisoning began to appear in Bangladesh, where the problem was found to be even more severe than in West Bengal.

How the water came to contain such high levels of arsenic is still a matter for conjecture. Why the distribution of arsenic contamination is so maddeningly random is still not known. The only timely recourse seemed to lie in testing each well and painting the pumps red if they were contaminated and green if they were safe. The water's arsenic content tends to change with the time and season, however. Much deeper tubewells were more likely to be safe but were more expensive, and replacing the hundreds of thousands of contaminated shallow tubewells could take years.

1970s, a quarter of a million children died each year from water-borne communicable diseases such as cholera and dysentery. In what better hands to place this catastrophe than those of UNICEF, the United Nations children's fund?

Acting under the purest of humanitarian motives, UNICEF proposed a solution that seemed a providential blend of economy and speed. Inexpensive iron tubes were pushed through the marshy ground to tap water stores just beneath the surface. When fitted with hand pumps, an inexhaustible supply of clean water seemed assured. By 1972, nearly a million such devices had been installed, and the health benefits were already evident. The mortality rate for children under five began to drop and was halved by 1996. Efforts to provide the entire area with safe water were redoubled, and now an estimated 95\% of rural inhabitants have access to at least one such well.

But in the background an unimagined horror was slowly emerging. The first confirmed report of arsenic contamination of tubewell water came as early as 1983 , but it was regarded as an isolated incident. A dermatologist at the Calcutta School of Tropical Medicine recognized the skin lesions, and had some West Bengali wells investigated. They tested positive for arsenic. By 1987, more than 1,000 cases had been identified. But papers published in local and international journals were largely ignored. Organized conferences and pleas for attention fell on the deaf ears of aid officials and government workers, who pointed to the obvious
This tragic but important story is told in the first two chapters of this slim volume, with some solutions proposed in the final chapter. In between the book deals with the history of arsenic. There is a unique section on the commercial uses of arsenic pigments, such as Scheele's green and emerald green, which satisfied a void in the colour spectrum for consumer products such as wallpaper. The use of arsenical dyes in the nineteenth century spread to clothing, paper, cardboard, soap, toys, paints, artificial and dried flowers, stuffed animals, Venetian blinds, curtains and ballgowns. They were even used as food colourings. The morbidity and mortality that resulted from this collective insanity will never be fully tabulated.

There is a chapter on the largely illadvised therapeutic uses of arsenic, and another on the homicidal application of arsenic, including some of the more famous poisoners and their victims. Also discussed is the ugly environmental impact of arsenic production or its release from the commercial smelting of ores for other materials.

There is certainly much here to fascinate a general audience but I found the book to be curiously disjointed. There is little mention of the biological mechanisms by which arsenic produces its effects, for example. Earth scientists may find enough to identify with, but perhaps the author could have been persuaded by his editor to provide a little more for life scientists.

Roger P. Smith is emeritus professor of pharmacology and toxicology, Dartmouth Medical School, Hanover, New Hampshire 03755, USA. 